\title{
Detection of vector-borne pathogens in cats and their ectoparasites in southern Italy
}

\author{
Maria-Flaminia Persichetti ${ }^{1 \dagger}$, Laia Solano-Gallego ${ }^{2^{*}+}$, Lorena Serrano ${ }^{3}$, Laura Altet ${ }^{3}$, Stefano Reale ${ }^{1}$,
} Marisa Masucci ${ }^{4}$ and Maria-Grazia Pennisi ${ }^{4+}$

\begin{abstract}
Background: Vector-borne pathogens are the subject of several investigations due to the zoonotic concern of some of them. However, limited data are available about the simultaneous presence of these pathogens in cats and their ectoparasites. The aim of the present study was to define the species of ectoparasites found on cats as well as to investigate vector-borne pathogens in cats and their ectoparasites in southern Italy.
\end{abstract}

Methods: Blood from 42 cats and fleas or flea pools $(n=28)$ and ticks $(n=73)$ collected from them were investigated by quantitative PCR for the detection of vector-borne pathogens. Feline serum samples were tested by IFAT to detect IgG antibodies against Leishmania infantum, Bartonella henselae, Rickettsia conorii, Rickettsia felis, Rickettsia typhi, Babesia microti, Ehrlichia canis and Anaplasma phagocytophilum antigens.

Results: Only one flea species (Ctenocephalides felis) and four tick species belonging to the genera Rhipicephalus and Ixodes were identified on cats from southern Italy. Molecular evidence of Bartonella spp., Rickettsia spp., hemoplasmas, Babesia vogeli and L. infantum was found in ectoparasites (fleas and/or ticks) while DNA from Hepatozoon felis and Ehrlichia/Anaplasma spp. was not detected. Likewise, DNAs from Bartonella, hemoplasma and Leishmania were the only pathogens amplified from feline blood samples. Cats had also antibodies against all the investigated pathogens with the exception of Rickettsia typhi. Agreement between serological and molecular results in individual cats and their ectoparasites was not found. The only exception was for Bartonella with a fair to moderate agreement between individual cats and their ectoparasites. Bartonella clarridgeiae was the species most frequently found in cats and their fleas followed by B. henselae.

Conclusions: In conclusion, cats harboring ticks and fleas are frequently exposed to vector-borne pathogens. Furthermore, ticks and fleas harbored by cats frequently carry pathogens of zoonotic concern therefore appropriate feline ectoparasiticide preventative treatments should be used in cats.

Keywords: Vector-borne pathogens, Flea, Tick, Cat

\section{Background}

Ticks, fleas and mosquitoes are globally distributed and their ability to transmit pathogens gives them important medical relevance. On the other hand, the growing success of pets in developed countries, especially the cat with its independent lifestyle, results in an increased risk for

\footnotetext{
* Correspondence: laia.solano@uab.cat

${ }^{\dagger}$ Equal contributors

${ }^{2}$ Departament de Medicina i Cirurgia Animal, Facultat de Veterinària. Universitat Autònoma de Barcelona, 08193, Bellaterra, Barcelona, Spain Full list of author information is available at the end of the article
}

humans of contact with feline ectoparasites [1]. It is well known that the most frequent flea species found on cats is Ctenocephalides felis [2]. Conversely, limited information is available about the species of ticks which infest cats and vector-borne pathogens (VBPs) harbored by them [2-10]. In addition, the comparison of vector-borne pathogens from cats and from their ectoparasites (fleas and ticks) has not been fully explored [11].

The aims of this investigation which was carried out in two regions (Calabria and Sicily) of southern Italy were: (i) to evaluate the flea and tick species collected from 
outdoor domestic cats and determine if they harbor VBPs; (ii) to evaluate exposure of outdoor cats to VBPs by means of antibody and molecular testing; and (iii) to compare the VBPs DNA from feline blood and from the ectoparasites (fleas and ticks) collected from them.

\section{Methods}

The present study integrates data already published on 132 ticks collected from a large number of cats $(n=308)$ in Southern Italy and the pathogens that they harbor [4]. We included in this study a total of 42 cats from province of Reggio Calabria $(n=27)$ and from Messina city and Lipari Island in Sicily region $(n=15)$ enrolled between March 2012 and January 2013. These cats were selected based on the following criteria: the presence of at least one ectoparasite (tick or flea) on physical examination, residual ethylenediaminetetraacetic acid (EDTA) blood and serum samples available, signed owner informed consent and outdoor life style. Both sick $(22 / 42=52.4 \%)$ and apparently healthy cats $(20 / 42=47.6 \%)$ based on clinical history and physical examination were enrolled. Date of sampling, gender, age, breed, lifestyle, vaccination status, ongoing therapy, reason for consultation, physical examination, the number of collected ectoparasites, feeding status of collected ticks as well as antiparasitic treatments of cats were recorded.

Each cat was carefully combed for at least five minutes throughout the whole body surface and inspected for the presence of fleas or/and ticks. All ectoparasites detected were removed by a veterinarian and stored in alcohol $70 \%$ as a preventative measure. Feline blood residual samples were employed in the present study. Therefore, ethical committee approval was not needed. Informed consent was obtained from all owners and from the legal representative of animal welfare groups in charge of the management of stray cats.

Serum from all cats was tested for the detection of immunoglobulin G (IgG) antibodies against Bartonella henselae, Rickettsia conorii, Rickettsia felis, Rickettsia typhi, Ehrlichia canis, Babesia microti and Anaplasma phagocytophilum antigens by the immunofluorescence antibody test (IFAT) using commercial kits (Fuller Laboratories Fullerton, California, USA). The manufacturer's protocol was followed for all serological tests using a cut-off dilution of 1:64 for B. henselae, $R$. conorii, $R$. felis, $R$. typhi and $B$. microti; and 1:50 for E. canis and A. phagocytophilum. The presence of $L$. infantum IgG antibodies was investigated using L. infantum (strain MHOM/IT/80/IPT1) antigen slides manufactured by the National reference centre for Leishmaniosis, (C.Re.Na.L, Palermo, Italy) and fluoresceinated rabbit anti-cat IgG (Anti-IgG-FITC, SIGMA) diluted in PBS 1:200 [12]. The cut-off value was established at 1:80 for L. infantum [12].
Morphometric identification of fleas and ticks was made through a stereomicroscope before DNA extraction for polymerase chain reaction (PCR) assays [13, 14]. Afterwards, fleas from each cat were extracted and processed and only for cats carrying more than one single flea, pools were done. Specifically, a number spanning from two to five fleas collected from each cat was pooled for molecular investigations. Conversely, ticks were in any case extracted and processed individually.

DNA extraction from $300 \mu \mathrm{l}$ of blood was performed using High Pure PCR Template preparation kit (Roche, Mannheim, Germany). DNA was eluted in $100 \mu \mathrm{L}$ of elution buffer and stored at $-20{ }^{\circ} \mathrm{C}$ until used. DNA extraction from individual ticks, fleas and flea pools was carried out using High Pure PCR Template preparation kit (Roche, Mannheim, Germany) according to the manufacturer's tissue protocol with some modifications. Briefly, all ectoparasites were washed twice in sterile PBS solution for 5 min shaking it slowly, then overnight at $4{ }^{\circ} \mathrm{C}$. Each flea was manually cut by a sterile lancet in four pieces and then suspended in $200 \mu \mathrm{l}$ of Tissue Lysis Buffer of the same kit. DNA was eluted in $50 \mu \mathrm{l}$ of elution buffer and stored at $-20{ }^{\circ} \mathrm{C}$ for later analysis.

Real-time PCR technology was applied as described elsewhere [4], to identify specific DNA target for Ehrlichia/ Anaplasma spp., piroplasmids (Babesia spp. and Theileria spp.), Hepatozoon felis, hemotropic Mycoplasma spp., Rickettsia spp., Bartonella spp. and L. infantum from ticks and feline blood samples while only the last four pathogens were investigated on fleas due to economical restrictions. All positive PCR results for each ectoparasite or cat were sequenced according to the Big-Dye Terminator Cycle Sequencing Ready reaction Kit (AB, Life Technologies) using the same primers. Sequences obtained were compared with GenBank database (www.ncbi.nlm.nih.gov/BLAST). All positive PCR results for hemoplasmas or L. infantum were not sequenced. Instead, species-specific real time PCRs were performed as described by Martinez et al. [15] to discriminate among feline hemoplasmas species (Mycoplasma haemofelis (Mhf), 'Candidatus Mycoplasma haemominutum' (CMhm) and 'Candidatus Mycoplasma turicencis' $(C M t))$ as well as for L. infantum real time PCR [16].

For each pathogen investigated, Kappa agreement test (GraphPad InStat) was used to establish agreement between serological and molecular results in cats, between molecular results in cats, ticks or fleas and between serological results in cats and molecular results in ticks or fleas. The Kappa values were evaluated as follows: no agreement $(k<0)$, slight agreement $(0<k<$ $0.2)$, fair agreement $(0.2<k<0.4)$, moderate agreement $(0.41<k<0.6)$, substantial agreement $(0.61<k<0.8)$ and almost perfect agreement $(k>0.81)$. 


\section{Results}

\section{Clinical data and antibody detection in cats}

Age of cats ranged from six months to ten years with a median of 1.5 years. Twenty-three cats were females and 19 were males. Only six were not neutered. Thirty-nine were mixed breed domestic short hair cats and six mixed breed domestic long hair cats. Information on ectoparasiticide treatment was available for 40 cats and most of them $(35 / 40=87.5 \%)$ were never treated with ectoparasiticide. One cat was only treated during the summer season but the other four cats were monthly treated. Ticks were also detected on these five treated cats.

Thirty-nine of the 42 cats examined (92.9\%) were antibody positive to at least one investigated antigen. Antibodies were detected against all the VBPs studied except for $R$. typhi antigens (Table 1).

\section{Detection and morphological identification of ticks and fleas}

Sixty-ffwas infested by both ticks and fleasive fleas were collected from 28 out of the 42 cats and all were identified as C. felis. Seventy-three ticks were also removed from 15 cats and only one cat (from Calabria) was infested by both ticks and fleas. Ticks belonged to the genera Rhipicephalus ( $n$ $=42$ ) and Ixodes $(n=31)$ and 25 specimens were engorged. In detail, 25 Rhipicephalus sanguineus (3 engorged), 17 Rhipicephalus pusillus, 19 Ixodes ventalloi (16 engorged), ten Ixodes ricinus (four engorged), two engorged Ixodes spp. were identified. The number of ectoparasites collected from individual cats ranged from one to five fleas with a median value of two fleas and one to 21 ticks with a median value of four ticks. Fleas were mostly $(27 / 28=96 \%)$ collected from cats in Calabria Province with the exception of one male flea that was removed from a cat living in Messina city. In contrast, all ticks were found on cats from Lipari island (Messina province) $(14 / 15=93 \%)$ with the exception of one tick (Ixodes ricinus engorged female) that was removed from a cat living in Calabria Province $(1 / 15=7 \%)$.

Table 1 Serological results of investigated pathogens in 42 cats infested by ectoparasites

\begin{tabular}{ll}
\hline Antigen & Number of seropositive cats (\%) \\
\hline Bartonella henselae & $23(54.8)$ \\
Rickettsia conorii & $23(54.8)$ \\
Anaplasma phagocytophilum & $14(33.3)$ \\
Babesia microti & $10(23.8)$ \\
Ehrlichia canis & $6(14.3)$ \\
Leishmania infantum & $1(2.4)$ \\
Rickettsia felis & $1(2.4)$ \\
Rickettsia typhi & $0(0)$ \\
\hline
\end{tabular}

Molecular results on ticks, fleas and feline blood samples Almost all fleas (96.4\%), $19.2 \%$ of ticks and $42.8 \%$ of cats were found PCR-positive to at least one investigated pathogen. PCR results from ticks, fleas and cats are summarized in Table 2.

Bartonella clarridgeiae was confirmed by sequencing in seven cats $(16.6 \%)$, in 16 pools of fleas $(57.1 \%)$ and in two ticks (1.5\%). Bartonella henselae was confirmed by sequencing in nine cats $(21.4 \%)$ and in only four pools of fleas (14.3\%). DNA sequences were 99-100\% identical to both Bartonella species available in GenBank (B. clarridgeiae (GenBank ID: FN645454.1) and B. henselae (GenBank ID: KF466255.1). Similarly, L. infantum DNA was amplified from three cats, two fleas or pools and eight ticks.

Interestingly, DNA of hemoplasmas was not amplified from any of the ectoparasites but 11 feline blood samples were positive. Briefly, seven $M h f$, seven $C M h m$ and four CMt DNAs were detected in cats. Babesia vogeli was only amplified from one tick with a $100 \%$ identity of GenBank sequences (GenBank ID: JX871885.1).

Rickettsia monacensis and $R$. helvetica were detected in five ticks and DNA sequences were 98-100\% identical to GenBank sequences ( $R$. monacensis (GenBank ID: KF016136.1) and $R$. helvetica (GenBank ID: JQ796866.1). Rickettsia felis was found in 23 flea pools or single fleas with an identity of $100 \%$ of GenBank sequences (GenBank ID: KF245441.1).

Six out of 25 engorged ticks were PCR positive to at least one investigated pathogen but they never harbored the same microorganisms of the host cat. Individual results of serology and PCR from cats and their ectoparasites are listed in Tables 3 and 4. In feline blood, the most frequent co-infection was among different hemoplasma species $(n=6)$. Moreover, co-infection was found between Bartonella spp. and hemoplasmas $(n=3)$. Leishmania

Table 2 Results of pathogens investigated by PCR in ticks, fleas and cats

\begin{tabular}{|c|c|c|c|}
\hline \multirow[t]{2}{*}{ Pathogens } & \multicolumn{3}{|c|}{$\begin{array}{l}\text { Number of positive ticks, fleas or cats/ } \\
\text { total number of ticks, fleas or cats (\%) }\end{array}$} \\
\hline & Ticks & Fleas $^{a}$ & Feline blood \\
\hline Bartonella spp. & $2 / 73(2.7)$ & $20 / 28(71.4)$ & $16 / 42(38.1)$ \\
\hline Hemoplasmas & $0(0)$ & $0(0)$ & $11 / 42(26.2)$ \\
\hline Rickettsia spp. & $5 / 73(6.8)$ & $23 / 28(82.1)$ & $0(0)$ \\
\hline Ehrlichia spp./Anaplasma spp. & $0(0)$ & $\mathrm{NE}$ & $0(0)$ \\
\hline Piroplasmid & $1 / 73(1.4)$ & NE & $0(0)$ \\
\hline Hepatozoon felis & $0(0)$ & NE & $0(0)$ \\
\hline Leishmania infantum & 8/73 (10.9) & $2 / 28(7.1)$ & $3 / 42(7.1)$ \\
\hline Total $(\%)^{b}$ & $14 / 73(19.2)$ & $27 / 28(96.4)$ & $18 / 42(42.8)$ \\
\hline
\end{tabular}


Table 3 Distribution of serological and PCR results in cats and in their ticks

\begin{tabular}{|c|c|c|c|}
\hline \multirow[t]{2}{*}{$\begin{array}{l}\text { Number } \\
\text { of cats }\end{array}$} & \multirow{2}{*}{$\begin{array}{l}\text { Pathogens exposure } \\
\text { confirmed by antibody } \\
\text { detection in cats }\end{array}$} & \multicolumn{2}{|c|}{$\begin{array}{l}\text { Pathogens identified } \\
\text { by real-time PCRs }\end{array}$} \\
\hline & & Cat & Ticks \\
\hline 1 & R. conorii, B. microti & None & None \\
\hline 2 & R. conorii, A. phagocytophilum & None & None \\
\hline 1 & $\begin{array}{l}\text { B. henselae, R. conorii, E. canis, } \\
\text { A. phagocytophilum }\end{array}$ & L. infantum & None \\
\hline 1 & $\begin{array}{l}\text { B. henselae, R. conorii, } \\
\text { A. phagocytophilum }\end{array}$ & $\begin{array}{l}\text { B. henselae, } \\
\text { CMhm }\end{array}$ & None \\
\hline 1 & B. henselae, B. microti & B. henselae & None \\
\hline 1 & R. conorii, A. phagocytophilum & Mhf & None \\
\hline 1 & R. conorii, B. microti & None & L. infantum \\
\hline 1 & B. henselae, B. microti & B. henselae & L. infantum \\
\hline 1 & B. henselae, R. conorii, B. microti & CMhm, CMt & B. clarridgeiae \\
\hline $1^{\mathrm{b}}$ & Negative & Mhf, CMhm & R. monacensis \\
\hline 1 & A. phagocytophilum & B. clarridgeiae & $\begin{array}{l}\text { R. monacensis, } \\
\text { L. infantum }\end{array}$ \\
\hline 1 & B. microti & None & $\begin{array}{l}\text { B. vogeli } \\
\text { L. infantum }\end{array}$ \\
\hline 1 & $\begin{array}{l}\text { B. henselae, R. conorii, } \\
\text { A. phagocytophilum }\end{array}$ & $\begin{array}{l}\text { B. henselae, } \\
\text { Mhf, CMhm }\end{array}$ & $\begin{array}{l}\text { B. clarridgeiae, } \\
\text { L. infantum }\end{array}$ \\
\hline $1^{\mathrm{a}}$ & $\begin{array}{l}\text { R. conorii, R. felis, } \\
\text { E. canis, B. microti }\end{array}$ & None & $\begin{array}{l}\text { R. helvetica, } \\
\text { R. monacensis, } \\
\text { L. infantum }\end{array}$ \\
\hline
\end{tabular}

Abbreviations: Mhf Mycoplasma haemofelis, CMhm Candidatus Mycoplasma haemominutum, CMt Candidatus Mycoplasma turicensis

${ }^{a}$ Cat infested by 21 ticks; ${ }^{b}$ Cat infested by both ticks and fleas

infantum DNA was also amplified in one cat positive to both B. henselae and B. clarridgeiae.

Molecular investigations detected DNA of different pathogens in single ticks. Briefly, L. infantum DNA was amplified in three ticks already positive to $B$. clarridgeiae, $R$. monacensis and $B$. vogeli and another tick was found positive to both $R$. monacensis and $R$. helvetica.

In fleas, the most frequent co-infection was between $R$. felis and B. clarridgeiae that was found in pools but also in one single flea. Only four fleas, collected from a PCR negative cat, were positive at the same time to three pathogens (R. felis, B. clarridgeiae and L. infantum).

The agreement between serological Bartonella results in cats and PCR data was moderate with ticks $(k=0.461$; accuracy 0.79$)$, followed by a fair agreement with feline blood $(k=0.395$; accuracy 0.69$)$ and with fleas $(k=0.292$; accuracy 0.68 ). A fair or slight agreement was respectively observed between $B$. henselae PCR results in cats and in fleas $(k=0.340$; accuracy 0.82$)$ as well as for $B$. clarridgeiae ( $k=0.208$; accuracy 0.57$)$. Agreement between serological and molecular results for other pathogens in individual cats and their ectoparasites was slight or not found.
Table 4 Distribution of serological and PCR results in cats and in their fleas

Number Pathogens exposure confirmed Pathogens identified

of cats by antibody detection in cats by real-time PCRs

\begin{tabular}{|c|c|c|c|}
\hline & \\
\hline & & Cats & Fleas \\
\hline 1 & B. henselae & None & None \\
\hline 1 & B. henselae & None & B. henselae \\
\hline 1 & Negative & $\begin{array}{l}\text { Mhf, B. } \\
\text { clarridgeiae }\end{array}$ & B. clarridgeiae \\
\hline 2 & B. henselae & B. henselae & B. clarridgeiae \\
\hline 1 & Negative & None & R. felis \\
\hline $1^{a}$ & Negative & Mhf, CMhm & R. felis \\
\hline 1 & R. conorii & None & R. felis \\
\hline 1 & B. henselae & CMhm, CMt & R. felis \\
\hline 1 & B. henselae, R. conorii & CMhm, CMt & R. felis \\
\hline 1 & $\begin{array}{l}\text { R. conorii, } \\
\text { A. phagocytophilum }\end{array}$ & None & R. felis \\
\hline 1 & B. henselae, R. conorii & $\begin{array}{l}\text { B. henselae, } \\
\text { L. infantum }\end{array}$ & $\begin{array}{l}\text { B. henselae, } \\
\text { R. felis }\end{array}$ \\
\hline 1 & B. henselae & B. clarridgeiae & $\begin{array}{l}\text { B. henselae, } \\
\text { R. felis }\end{array}$ \\
\hline 1 & $\begin{array}{l}\text { B. henselae, } \\
\text { A. phagocytophilum }\end{array}$ & B. henselae & $\begin{array}{l}\text { B. henselae, } \\
\text { R. felis }\end{array}$ \\
\hline 2 & R. conorii & None & $\begin{array}{l}\text { B. clarridgeiae, } \\
\text { R. felis }\end{array}$ \\
\hline 1 & A. phagocytophilum & None & $\begin{array}{l}\text { B. clarridgeiae, } \\
\text { R. felis }\end{array}$ \\
\hline 1 & $\begin{array}{l}\text { B. henselae, R. conorii, } \\
\text { E. canis, B. microti, } \\
\text { L. infantum }\end{array}$ & None & $\begin{array}{l}\text { B. clarridgeiae, } \\
\text { R. felis }\end{array}$ \\
\hline 1 & B. henselae, B. microti & $\begin{array}{l}\text { Mhf, CMhm, } \\
\text { CMt }\end{array}$ & $\begin{array}{l}\text { B. clarridgeiae, } \\
\text { R. felis }\end{array}$ \\
\hline 1 & R. conorii & Mhf & $\begin{array}{l}\text { B. clarridgeiae, } \\
\text { R. felis }\end{array}$ \\
\hline 1 & B. henselae, R. conorii & B. henselae & $\begin{array}{l}\text { B. clarridgeiae, } \\
\text { R. felis }\end{array}$ \\
\hline 1 & B. henselae, E. canis & B. clarridgeiae & $\begin{array}{l}\text { B. clarridgeiae, } \\
\text { R. felis }\end{array}$ \\
\hline 1 & $\begin{array}{l}\text { B. henselae, R. conorii, } \\
\text { E. canis, A. phagocytophilum }\end{array}$ & B. clarridgeiae & $\begin{array}{l}\text { B. clarridgeiae, } \\
\text { R. felis }\end{array}$ \\
\hline 1 & B. henselae, B. microti & B. clarridgeiae & $\begin{array}{l}\text { B. clarridgeiae, } \\
\text { R. felis }\end{array}$ \\
\hline 1 & B. henselae & Mhf & $\begin{array}{l}\text { B. clarridgeiae, } \\
\text { R. felis }\end{array}$ \\
\hline 1 & A. phagocytophilum & $\begin{array}{l}\text { B. clarridgeiae, } \\
\text { L. infantum }\end{array}$ & $\begin{array}{l}\text { B. clarridgeiae, } \\
\text { R. felis }\end{array}$ \\
\hline 1 & $\begin{array}{l}\text { R. conorii, } \\
\text { A. phagocytophilum }\end{array}$ & None & $\begin{array}{l}\text { R. felis, } \\
\text { L. Infantum }\end{array}$ \\
\hline 1 & $\begin{array}{l}\text { B. henselae, R. conorii, } \\
\text { E. canis, A. phagocytophilum }\end{array}$ & None & $\begin{array}{l}\text { B. clarridgeiae, } \\
\text { R. felis, } \\
\text { L. Infantum }\end{array}$ \\
\hline
\end{tabular}

Abbreviations: Mhf Mycoplasma hemofelis, CMhm Candidatus Mycoplasma haemominutum, CMt Candidatus Mycoplasma turicensis

${ }^{\mathrm{a}}$ Cat infested by both ticks and fleas 


\section{Discussion}

In this study, we confirmed $C$. felis as the unique flea species found in cats from Southern Italy mainly in Calabria Province. In contrast, species of Rhipicephalus and Ixodes were found as the only tick species collected from cats mainly living in Lipari Island (Sicily) [4]. Ecological factors, season of sampling, climatic variations may be responsible for these findings. Moreover, outdoor cats from Lipari Island are free roaming in a wild habitat and therefore they are in close contact with wild rabbits and birds and their ectoparasites.

Almost all fleas (96.4\%), $19.2 \%$ of ticks and $42.8 \%$ of cats were found PCR positive to at least one investigated pathogen. The most common pathogens identified by molecular techniques were of zoonotic concern and include Rickettsia, Bartonella and L. infantum, however with different distribution and rate of infection in cats and their ectoparasites. For instance, Rickettsia spp. DNA was exclusively amplified from the ectoparasites ( $R$. helvetica and $R$. monacensis from ticks and $R$. felis from fleas) supporting a possible role for cofeeding transmission in the maintenance of these pathogens within the vector population as already demonstrated for $R$. conorii israelensis in $R$. sanguineus ticks [17] and for $R$. felis in fleas (C. felis and Xenopsilla cheopis) [18]. These rickettsial species can cause febrile illness among other clinical manifestations in humans as well established for R. felis [19] and also described for $R$. helvetica and $R$. monacensis [20]. Therefore, it is important to highlight that cats will be carriers of ectoparasites and associated Rickettsia species to humans suggesting a zoonotic potential but they do not appear to be reservoirs of these infections. Conversely, Bartonella DNA (B. clarridgeiae and B. henselae) was the most frequent pathogen found in cats suggesting an important zoonotic risk to humans [21] as carriers of ectoparasites and apparent reservoirs for both infections [22]. Moreover, hemoplasma (Mhf, CMt, CMhm) DNA was detected only in cat blood confirming the potential limited role of vectors in their transmission [23, 24] despite DNA of some hemotropic mycoplasmas can be found in ectoparasites collected from cats $[11,25,26]$.

It is noteworthy that L. infantum DNA was found in 7-10\% of ectoparasite or cat blood samples and it was the most common parasite found in ticks. Interestingly, this is the first bona fide report of L. infantum DNA from cat fleas. DNA from Bartonella henselae, B. clarridgeiae, $R$. monacensis, $R$. helvetica, $R$. felis, M. haemofelis, Ca. M. haemominutum, Ca. M. turicensis, B. vogeli and $L$. infantum was amplified in feline blood and/or in ectoparasites. Vector-borne pathogens found in this study partly confirm previous data reported in Italy from cats or their ectoparasites [8-10, 27, 28]. However, we obtained data at the same time from cats and the ticks and fleas they harbor.
Detection of antibodies against most of the investigated VBPs and/or of circulating pathogen DNA showed that cats harboring ticks or fleas are frequently exposed to VBPs in the geographic area under study. In fact as much as half of cats had antibodies against $R$. conorii and $B$. henselae and the percentage of detectable antibodies against $A$. phagocytophilum, B. microti and E. canis was not negligible confirming data previously reported in Italy [10] and throughout Europe [6, 29-31]. Interestingly, in the present study, a very low $R$. felis antibody rate was observed (2.4\%) as well as no detection of $R$. felis DNA in any feline blood samples as reported in other studies $[26,32,33]$. Our findings are in disagreement with other data that reported higher $R$. felis antibody rates (16.3\%) in Spain [33] as well as R. felis DNA detection (28\%) in feline blood from Bangladesh cats [34]. In the present study, high $R$. conorii antibody rates were found in the absence of rickettsiemia as previously reported in other studies in cats [29]. Similar findings are also observed in dogs with high $R$. conorii antibody rates and low rickettsiemia in endemic areas [35]. However, the present findings are in disagreement with a study performed in northeastern Spain where Rickettsia DNA similar to $R$. conorii or $R$. massiliae was found in $10 \%$ of cats [36]. Obviously, we cannot exclude that infections caused by other Rickettsia species of the spotted fever group circulating in southern Italy such as $R$. massiliae among others, contributed to this high antibody prevalence [36, 37]. It is well known that cross-reactions are common among Rickettsia species and this is a limitation of antibody prevalence studies [38]. Sicily and Calabria are Italian regions with a high incidence of human rickettsial diseases [39] and it is of peculiar interest to clarify the role of cats in their eco-epidemiology. In contrast with Spanish data [40], no serological and molecular traces of $R$. typhi were observed in both cats and ectoparasites.

Agreement between the majority of pathogens based on molecular or antibody detection among cats and in their ectoparasites was not found. The only exception was for fleas which were DNA positive to Bartonella (four for B. henselae and five to B. clarridgeiae). These fleas were collected from cats which were antibody and/or PCR positive to the same pathogen. Lappin et al. reported that almost all cats $(94.7 \%)$ infected by $B$. clarridgeiae carried B. clarridgeiae infected fleas and they suggested that $C$. felis may be a vector for this pathogen [11]. Conversely, in Taiwan, researchers found a high prevalence of fleas PCR positive for $B$. clarridgeiae and a very low prevalence of this bacterium in cats. They raised the hypothesis that $B$. clarridgeiae is more adapted to the flea than to the vertebrate host [5]. Other studies found a higher prevalence of Bartonella and hemoplasma DNA in fleas than in cat blood, but no data were given about positivity of fleas and 
their corresponding cat host $[31,41]$. In this study, $B$. clarridgeiae was the microorganism most frequently found simultaneously in fleas and their feline host.

To the best of our knowledge, no studies compared the molecular detection of pathogens in ticks removed from cats and their host. Host molecular negativity for pathogens found in ectoparasites may depend on the vector competence. For tick-borne pathogens, the transmission occurs at different times after the beginning of the blood meal depending upon specific life cycle characteristics [24]. Moreover, the bacteremia of some VBPs is transient, lasting a few hours, as reported for Rickettsia spp. and E. canis in dogs. This makes it difficult to detect the pathogens in the blood stream [24]. The low level of circulating pathogens requires highly sensitive molecular tools.

\section{Conclusions}

In conclusion, cats harboring ticks and fleas are frequently exposed to many VBPs. However, the simultaneous detection of VBPs in the hosts and their ectoparasites is uncommon with the exception of Bartonella. Bartonella clarridgeiae followed by $B$. henselae were the species most frequently found at the same time in fleas and the cat host.

Ticks and fleas harbored by cats frequently carry pathogens of zoonotic concern. As a preventative measure, the appropriate use of ectoparasiticide treatments is strongly recommended for use in cats.

\section{Abbreviations \\ ${ }^{\circ} \mathrm{C}$ : Celsius degree; Bp: base pairs; DNA: deoxyribonucleic acid; EDTA: ethylenediamine tetraacetic acid; IFAT: immunofluorescence antibody test; IgG: Immunoglobulins $\mathrm{G}$; $k$ : k agreement; min: minutes; n: number; OR: Odds Ratio; PBS: Phosphate buffered saline; PCR: Polymerase Chain Reaction; VBPs: Vector-Borne Pathogens; $\mu$ L: microliters.}

\section{Competing interests}

The authors declare that they have no competing interests.

\section{Authors' contributions}

MGP and LSG conceived the research study. MFP worked in the field. MFP contributed with data analysis and interpretation, wrote the first draft and revised the manuscript. MFP performed identification of ectoparasites and laboratory techniques. MFP, MGP and MM performed serological analysis. LA, LS and SR supervised the performance of molecular techniques. LSG and MGP contributed with data analysis and interpretation and wrote and revised the manuscript. All authors read and approved the final version of the manuscript.

\section{Acknowledgements}

The authors are grateful to Angela Burrascano for technical collaboration for serological techniques and to Tatiana Proboste for helping with morphological identification of ticks. The authors also thank Dr. Shazia Hosein for English revision of the manuscript.

This clinical study was funded by Bayer Animal Health Care-Animal Health Division (Monheim, Germany). Publication fees of this manuscript have been sponsored by Bayer HealthCare - Animal Health division, in the framework of the $11^{\text {th }}$ CVBD World Forum Symposium.

\section{Author details}

'Istituto Zooprofilattico Sperimentale della Sicilia Adelmo Mirri, Via G. Marinuzzi 3, 90129 Palermo, Italy. ${ }^{2}$ Departament de Medicina i Cirurgia
Animal, Facultat de Veterinària. Universitat Autònoma de Barcelona, 08193, Bellaterra, Barcelona, Spain. ${ }^{3}$ Vetgenomics, Edifici Eureka, PRUAB, 08193, Bellaterra, Barcelona, Spain. ${ }^{4}$ Dipartimento di Scienze Veterinarie, Università di Messina, Polo Universitario Annunziata, 98168 Messina, Italy.

Received: 14 March 2016 Accepted: 25 April 2016

Published online: 10 May 2016

\section{References}

1. Dantas-Torres F, Otranto D. Dogs, cats, parasites, and humans in Brazil: opening the black box. Parasit Vectors. 2014;7:22.

2. Otranto D, Dantas-Torres F. Canine and feline vector-borne diseases in Italy: current situation and perspectives. Parasit Vectors. 2010;3:2.

3. Maggi RG, Ericson M, Mascarelli PE, Bradley JM, Breitschwerdt EB. Bartonella henselae bacteremia in a mother and son potentially associated with tick exposure. Parasit Vectors. 2013;6:101.

4. Pennisi M-G, Persichetti M-F, Serrano L, Altet L, Reale S, Gulotta L, et al. Ticks and associated pathogens collected from cats in Sicily and Calabria (Italy). Parasit Vectors. 2015;8:512

5. Tsai Y-L, Lin C-C, Chomel BB, Chuang S-T, Tsai K-H, Wu W-J, et al. Bartonella infection in shelter cats and dogs and their ectoparasites. Vector Borne Zoonotic Dis. 2011;11:1023-30.

6. Ayllón T, Diniz PPVP, Breitschwerdt EB, Villaescusa A, Rodríguez-Franco F, Sainz A. Vector-borne diseases in client-owned and stray cats from Madrid, Spain. Vector Borne Zoonotic Dis. 2012;12:143-50.

7. Vilhena H, Martinez-Díaz VL, Cardoso L, Vieira L, Altet L, Francino O, et al. Feline vector-borne pathogens in the north and centre of Portugal. Parasit Vectors. 2013;6:99.

8. Spada E, Proverbio D, Galluzzo P, Della Pepa A, Perego R, Bagnagatti De Giorgi $\mathrm{G}$, et al. Molecular study on selected vector-borne infections in urban stray colony cats in northern Italy. J Feline Med Surg. 2014;16:684-8.

9. Spada E, Proverbio D, Galluzzo P, Della Pepa A, Bagnagatti De Giorgi G, Perego $R$, et al. Prevalence of haemoplasma infections in stray cats in northern Italy. ISRN Microbiol. 2014;2014:298352.

10. Spada E, Proverbio D, Galluzzo P, Perego R, Bagnagatti De Giorgi G Roggero N, et al. Frequency of piroplasms Babesia microti and Cytauxzoon felis in stray cats from northern Italy. BioMed Res Int. 2014;2014:943754.

11. Lappin MR, Griffin B, Brunt J, Riley A, Burney D, Hawley J, et al. Prevalence of Bartonella species, haemoplasma species, Ehrlichia species, Anaplasma phagocytophilum, and Neorickettsia risticii DNA in the blood of cats and their fleas in the United States. J Feline Med Surg. 2006:8:85-90.

12. Pennisi MG, Lupo T, Malara D, Masucci M, Migliazzo A, Lombardo G. Serological and molecular prevalence of Leishmania infantum infection in cats from Southern Italy. J Feline Med Surg. 2012;14:656-7.

13. Ménier K, Beaucournu JC. Taxonomic study of the genus Ctenocephalides Stiles \& Collins, 1930 (Insecta: Siphonaptera: Pulicidae) by using aedeagus characters. J Med Entomol. 1998;35:883-90.

14. Manilla G. Acari: Ixodida. Vol. XXXVI di Fauna D'Italia. Bologna: Ed. Calderini; 1998.

15. Martínez-Díaz VL, Silvestre-Ferreira AC, Vilhena H, Pastor J, Francino O, Altet L. Prevalence and co-infection of haemotropic mycoplasmas in Portuguese cats by real-time polymerase chain reaction. J Feline Med Surg. 2013;15: 879-85.

16. Vitale F, Caracappa S, Manna L, Gravino A, Reale S. Leishmania infantum minicircle DNA sequencing analysis and diagnosis by PCR. In: Proceedings of the Second World Congress on Leishmaniasis (WL2). Crete; 2001.

17. Zemtsova G, Killmaster LF, Mumcuoglu KY, Levin ML. Co-feeding as a route for transmission of Rickettsia conorii israelensis between Rhipicephalus sanguineus ticks. Exp Appl Acarol. 2010;52:383-92.

18. Brown LD, Christofferson RC, Banajee KH, Del Piero F, Foil LD, Macaluso KR. Cofeeding intra- and interspecific transmission of an emerging insect-borne rickettsial pathogen. Mol Ecol. 2015;24:5475-89.

19. Parola P. Rickettsia felis: from a rare disease in the USA to a common cause of fever in sub-Saharan Africa. Clin Microbiol Infect Off Publ Eur Soc Clin Microbiol Infect Dis. 2011;17:996-1000.

20. Oteo JA, Portillo A. Tick-borne rickettsioses in Europe. Ticks Tick-Borne Dis. 2012;3:271-8

21. Vayssier-Taussat M, Moutailler S, Féménia F, Raymond P, Croce O, La Scola B, et al. Identification of Novel Zoonotic Activity of Bartonella spp., France. Emerg Infect Dis. 2016;22:457-62. 
22. Chomel BB, Kasten RW. Bartonellosis, an increasingly recognized zoonosis. J Appl Microbiol. 2010;109:743-50.

23. Barker E, Tasker S. Haemoplasmas: lessons learnt from cats. N Z Vet J. 2013; 61:184-92.

24. Greene CE. Infectious diseases of the dog and cat. Bologna: Elsevier Health Sciences; 2013. p.1383.

25. Willi B, Boretti FS, Meli ML, Bernasconi MV, Casati S, Hegglin D, et al. Real-time $P C R$ investigation of potential vectors, reservoirs, and shedding patterns of feline hemotropic mycoplasmas. Appl Environ Microbiol. 2007;73:3798-802.

26. Assarasakorn S, Veir JK, Hawley JR, Brewer MM, Morris AK, Hill AE, et al. Prevalence of Bartonella species, hemoplasmas, and Rickettsia felis DNA in blood and fleas of cats in Bangkok. Thailand Res Vet Sci. 2012;93:1213-6.

27. Salvatore D, Aureli S, Baldelli R, Di Francesco A, Tampieri MP, Galuppi R. Molecular evidence of Leishmania infantum in Ixodes ricinus ticks from dogs and cats, in Italy. Vet Ital. 2014;50:307-12.

28. Giudice E, Di Pietro S, Alaimo A, Blanda V, Lelli R, Francaviglia F, et al. A molecular survey of Rickettsia felis in fleas from cats and dogs in Sicily (Southern Italy). PLoS One. 2014;9, e106820.

29. Solano-Gallego L, Hegarty B, Espada Y, Llull J, Breitschwerdt E. Serological and molecular evidence of exposure to arthropod-borne organisms in cats from northeastern Spain. Vet Microbiol. 2006;118:274-7.

30. Alves AS, Milhano N, Santos-Silva M, Santos AS, Vilhena M, de Sousa R. Evidence of Bartonella spp., Rickettsia spp. and Anaplasma phagocytophilum in domestic, shelter and stray cat blood and fleas, Portugal. Clin Microbiol Infect Off Publ Eur Soc Clin Microbiol Infect Dis. 2009;15(2):1-3.

31. Barrs VR, Beatty JA, Wilson BJ, Evans N, Gowan R, Baral RM, et al. Prevalence of Bartonella species, Rickettsia felis, haemoplasmas and the Ehrlichia group in the blood of cats and fleas in eastern Australia. Aust Vet J. 2010;88:160-5.

32. Millán J, Proboste T. Fernández de Mera IG, Chirife AD, de la Fuente J, Altet L. Molecular detection of vector-borne pathogens in wild and domestic carnivores and their ticks at the human-wild life interface. Ticks Tick-Borne Dis. 2016;7:284-90.

33. Gracia MJ, Marcén JM, Pinal R, Calvete C, Rodes D. Prevalence of Rickettsia and Bartonella species in Spanish cats and their fleas. J Vector Ecol J Soc Vector Ecol. 2015;40:233-9.

34. Ahmed R, Paul SK, Hossain MA, Ahmed S, Mahmud MC, Nasreen SA, et al. Molecular detection of Rickettsia felis in humans, cats, and cat fleas in Bangladesh, 2013-2014. Vector Borne Zoonotic Dis. 2016;16:356-8.

35. Solano-Gallego L, Caprì A, Pennisi MG, Caldin M, Furlanello T, Trotta M. Acute febrile illness is associated with Rickettsia spp. infection in dogs. Parasit Vectors. 2015;8:216.

36. Segura F, Pons I, Miret J, Pla J, Ortuño A, Nogueras M-M. The role of cats in the eco-epidemiology of spotted fever group diseases. Parasit Vectors. 2014; 7:353.

37. Otranto D, Dantas-Torres F, Giannelli A, Latrofa MS, Cascio A, Cazzin S, et al. Ticks infesting humans in Italy and associated pathogens. Parasit Vectors. 2014;7:328.

38. Wachter M, Wolfel S, Pfeffer M, Dobler G, Kohn B, Moritz A, et al. Serological differentiation of antibodies against Rickettsia helvetica, R. raoultii, R. slovaca, $R$. monacensis and $R$. felis in dogs from Germany by a micro-immunofluorescent antibody test. Parasit Vectors. 2015;8:126.

39. Ciceroni L, Pinto A, Ciarrocchi S, Ciervo A. Current knowledge of rickettsial diseases in Italy. Ann N Y Acad Sci. 2006;1078:143-9.

40. Nogueras MM, Pons I, Ortuño A, Miret J, Pla J, Castellà J, et al. Molecular detection of Rickettsia typhi in cats and fleas. PLoS One. 2013;8:e71386.

41. Kamrani A, Parreira VR, Greenwood J, Prescott JF. The prevalence of Bartonella, hemoplasma, and Rickettsia felis infections in domestic cats and in cat fleas in Ontario. Can J Vet Res Rev Can Rech Vét. 2008;72:411-9.

\section{Submit your next manuscript to BioMed Central and we will help you at every step:}

- We accept pre-submission inquiries

- Our selector tool helps you to find the most relevant journal

- We provide round the clock customer support

- Convenient online submission

- Thorough peer review

- Inclusion in PubMed and all major indexing services

- Maximum visibility for your research

Submit your manuscript at www.biomedcentral.com/submit

C Biomed Central 